\title{
Finding a middle ground between extremes: notes on researching transnational crime and violence.
}

\author{
Hannah E. Gill (Institute of Social and Cultural Anthropology, University \\ of Oxford)
}

Women anthropologists working in areas of conflict and risk must address specific practical and philosophical concerns, including the ethical issues involving the exposure of patterns of crime and violence in a community, limitation of movement and constant surveillance, and mistrust relating to the anthropologist's background. These issues are addressed in the context of the author's field research with a transnational migrant community in the Dominican Republic.

Anthropologists have worked in areas of conflict, violence, and warfare since Evans Pritchard researched the Nuer in Sudan. Fieldwork in insecure contexts has repelled some and attracted others, as in the case of Jeremy MacClancy (1988) escaping from his field site in Melanesia during its struggle for independence and, alternatively, Carolyn Nordstrom (1997) seeking out the front line in war-torn Mozambique. Early functionalist anthropologists stressed continuity and social stability instead of wider contexts of conflict and the disruptions of colonialism, while a more contemporary anthropology incorporates global contexts of insecurity and dissidence. One could argue, as Nancy Howell did in Surviving Fieldwork (1990) that all fieldwork is dangerous when factoring in illness, auto accidents and natural disaster. Whether an anthropologist sets out to study crime and violence in a community or unexpectedly finds herself living in a dangerous situation, risk is a factor in many fieldwork situations. The following comments concern contemporary practical and philosophical issues for dangerous fieldwork carried out by women researchers, and consider the following questions: What ethical issues does the anthropologist face when potentially exposing crime or violence patterns in a transnational community? How does the anthropologist work under conditions of constant surveillance and limitation of movement? How does she deal with the mistrust and even accusation relating to her own background? In a practical sense, how does she secure data and maintain her own safety? These considerations can be applied to all fieldwork and should therefore be made a priority in graduate training courses.

Risk was a daily part of my graduate fieldwork experience while completing an 18month multi-site ethnography of Dominican migration to the United States. Although I spoke Spanish and was ready for the challenge of being accepted into an AfroCaribbean community as a 26-year-old white American woman from the University of Oxford, I was ill prepared for living in an environment of crime and violence. I initially went to the Dominican Republic to study music and migration but my focus shifted when I found myself living in a rural community of people whose migrant families abroad in the United States were involved in drug trafficking operations. 
Many people in the community ${ }^{1}$ had relatives imprisoned in the United States or had been deported themselves. In addition to this unexpected finding, the community was located in a pocket of violent crime related to transnational migration patterns in an otherwise peaceful country. Disputes over drugs that originated in Boston and New York were 'resolved' at home in the Dominican Republic in often lethal ways, after which criminals could take advantage of the relative lack of law enforcement and their transnational mobility to escape to the United States. ${ }^{2}$ In this way, events that happen in Boston and New York have inevitable repercussions at home and the threat of violent retaliation against people involved in drugs and crime is very real for migrants and their families. The religious music I was investigating initially appeared to serve the purpose of helping migrants reach their destinations, but soon revealed a deeper involvement with extra-legal activities. Due to the community's marginality, most crimes, including murders, were never reported in newspapers, making it impossible to have known the insecurity of the field site ahead of time.

It did not take long to realize that crime would factor into my research: on the second day I found myself flattened under a car to avoid getting shot by a woman seeking revenge for her husband's murder in the town market, and on the third day I was sprinting away from a knife fight at a local hang-out. The following excerpt from my field notes reflects my initial reaction to the violence:

\section{March 2003}

This morning a man was shot in the middle of the vegetable market (!) Within minutes, the news of his death had spread by cell phone to his family's house two miles away, here in the village by the main road, as well as to the rest of the town. We were actually getting gas in the jeep across the street from the wife's house when she found out. We heard gunshots and people suddenly began to run out of her house. I didn't even know what was happening until someone jumped on me and pushed me on the ground. Another gunshot was fired and the woman ran out of the house with a rifle, yelling, got on the back of a motorcycle and drove off towards the centre of town. It was apparently a fight-the victim and his murderer had worked together selling drugs in Boston, and the victim had been arrested on drug charges in the U.S. and been bailed out by the killer. When he did not pay him back for the bail and skipped town, returning here, he was pursued and killed. That's the official story, anyway. The killer was long gone by the time the police arrived. He escaped to Santo Domingo and got on a flight to the U.S., according to our José, our neighbour who works for the police.

\section{March 2003}

This evening, while we were sitting around and helping with the packing for Nina's trip back to Boston (everything carefully wrapped and taped), we watched the local news on cable. Another murder in town, they reported - a guy killed, mistaken for his twin who was mixed up in drugs in Boston... The next story was of a woman was severely beaten and robbed a few blocks away from here (close-ups of the stitches in her face,

\footnotetext{
${ }^{1}$ The names of the community and its members have been omitted or changed to protect informants.

${ }^{2}$ While I continued to follow my original research agenda, my findings reflected the influence of crime on social relations, a topic that many community members had already engaged in and encouraged me to pursue. Although a formal research visa was not needed, I had to give a copy of my proposal to the director of the national museum of anthropology and present my findings at a public lecture.
} 
a chunk of hair out of her head). 'That's Morena's daughter'! everyone was yelling. Next story, a guy in town dies in a motorcycle accident-a close-up of his bashed-in head immediately after it happened, brains spilling out into the pavement. 'Is this normal'? I asked them. 'It's always like this when the dollar rises', said Abuelita.

Three days later, 70 hours before every television in the neighbourhood began to broadcast the first bombings in the U.S. war on Iraq, there was a drive by shooting in town (resulting in one death and one injury) aimed at the family involved in the killing several days before. I began to realize that violence would be an everyday part of field research, and I was right: over the next seven months there were 15 homicides in this small community, dozens of muggings, robberies, suicides, and violent confrontations.

\section{Minimizing risk}

In those first strange days of fieldwork, a re-evaluation of personal safety was necessary given the unexpected circumstances. First, I assessed the danger. As a young, white American graduate student, there was no way I could use camouflage as defense. Yet I was not a target and with necessary precautions I would be relatively safe. Considering the investment I had put into research up to that point, I decided to deal with the risk and attempt to turn it into a constructive experience. After several weeks my initial fear faded and I found it necessary to make periodic 'reality checks' with supervisors and colleagues abroad, which remind a researcher desensitized to violence and crime not to get too comfortable. I became aware that anthropological fieldwork breaks every Western rule of personal safety for women (and men): don't go to unfamiliar places alone, don't trust strangers, don't accept strange drinks or food from strangers, don't be out late at night, and don't make yourself vulnerable by living alone. But rules of personal safety are based on sticking to the familiar-the antithesis of anthropological research. If an anthropologist followed these rules, she would never go anywhere, try anything new, make any friends, or progress in research. Taking risks (or taking advantage of opportunities) and being independent is a crucial aspect of fieldwork, and to gain intimate understandings requires a lot of trust. The researcher must find a middle ground that allows her to take advantage of opportunities without compromising her own safety.

A great deal of risk can be reduced by simple precautions. I invested in a cell phone and began carrying mace and a 'dummy' wallet. Following the example of informants, I sewed hidden pockets into all of my clothes. I established links with trusted community members as well as the Peace Corps workers in the area so I could get an idea of hotspots before setting out for a day's fieldwork. This strategy of alliance with NGOs working in the area is effective for independent researchers, for NGO workers are connected to a much larger support system that keeps them informed of community happenings. These organizations will sometimes secure passports during fieldwork, another important precaution. Limiting alcohol intake was another extremely important practice, as well as leaving myself an exit strategy in all social situations.

For many women researchers, the advantages of living with a group, as part of a family, often outweigh the disadvantages, especially in an insecure area. I lived in an extended family household and am indebted to them for assuming responsibility for my safety. Although it was sometimes frustrating how they kept track of where I 
went, who I saw, and expected me home at designated times, the good sense of my decision became clear upon comparing my situation with women Peace Corps volunteers in the area whose programme forced them to live alone. Break-ins, arson and even sexual assault were realities that they constantly had to deal with. These practical considerations are important not only for researchers in areas of violence but in any location.

\section{Ethical considerations}

The unexpected element of crime and violence in the community not only necessitated a re-evaluation of personal safety but also ethical considerations that had not originally factored into a study of music on an otherwise peaceful Caribbean island. Would discussing my research in the context of crime, a very relevant factor, add to the already negative stereotypes that Dominican migrants face in U.S. society? If I chose to talk about the effects of crime, how would I balance the confidentiality of a community versus exposing the truth? Would the community, like Nancy Scheper Hughes' (1979) Irish informants be able to recognize family members even though all the people and place names would be changed in anything I published? I realized that my research, sensitively presented, might provide a background context for a complex problem that encompasses more than the minority of migrants (and U.S. citizens) involved in crime and drug trafficking in the U.S., a task that Philippe Bourgois set out to accomplish in his 1995 ethnography of Spanish Harlem. I hoped to provide an alternative perspective of people who, in their efforts to make a living by moving to the U.S., find themselves entangled in networks of crime and poverty. Understanding the mechanisms and conditions behind conflict and violence in a community is a large step towards alleviating these problems.

Transparency of research became a crucial part of methodology, involving dialogues with community leaders, academics, and journalists. Public presentations of research gauged reactions and potential repercussions. I gave a public lecture at the Museo del Hombre in Santo Domingo at which I presented my findings, emphasizing the connection of extra-legal activities, Vodú religion and its ritual palo music among Dominicans migrating to the U.S. This lecture was a way of testing if the conclusions I had drawn from my fieldwork made sense to community members in my field site, Dominican migrants, anthropologists, and other Dominican academics. It also was a 'feeling out' of the potential repercussions of writing about the controversial topic of drug involvement and undocumented migration. After the presentations, a group of palo musicians from the field site community gave a concert sponsored by a grant from the Benjamin Franklin Cultural Centre in Santo Domingo.

The audience consisted of over 100 people, including academics and journalists from the national newspapers, my 'family' and neighbours in the field site community who had travelled two hours by crowded bus, and the general public of Santo Domingo. The lecture was recorded and large parts of the text were published in the national newspaper Hoy in the 31 August 2004 issue. Audience members contributed many comments. One man said, 'Our community has a reputation throughout the Republic for being a hard-working people. You must be careful not to make us sound like we deal drugs'. Another man stood up and commented 'I think that more people should address the issue of drugs in our community, it's a growing problem with young people and migration only makes it worse. Our values of hard work and respect are changing with all these people coming home with money, acting like exhibitionists'. 
Another young Dominican man who had spent most of his adolescence in Washington Heights, New York City, commented (in English): 'I speak for the second generation in New York, and what you say rings true for us, even though no one ever talks about it'. While there was not and never will be a consensus among such a diverse audience, most comments were positive and supportive towards the research.

\section{Building trust}

Given the climate of fear and mistrust that often accompanies communities experiencing violence and conflict, being an outsider was a disadvantage overcome only by a long-term stay in the community, a tested anthropological fieldwork method. Suspicion toward everyone was manifested in very strict rules of social interaction that became a significant constraint on my freedom and mobility; two crucial factors for a researcher attempting to gain a holistic study of a community. While it was extremely advantageous to be living in a family homestead, I was taken in as a family member in a situation reminiscent of Abu-Lughod's fieldwork experience in Libya, recounted in her ethnography, Veiled Sentiments (1986). I was expected to behave myself as a respectful young Dominican woman would, which meant that I could not go anywhere alone or converse with certain people. Those certain people, it turned out, consisted of anyone not related to the family. An elaborate system of spying and gossip that had developed in the community protected people from suspicious characters, but also ensured that everyone knew what I was doing at all times.

Working under constant surveillance and restrictions against talking to certain valuable informants was frustrating at first because of their opaque justifications: no one seemed to have a good explanation for why I couldn't visit specific people. Recalling Elenore Smith Bowen's alienation from her Tiv village after rebelling against their ban on interviewing witches (1964), I wrestled with the consequences of 'breaking the rules' and interviewing whomever I wanted. ${ }^{3}$ The famous strategy of Napoleon Chagnon also came to mind; working in a society of violence, he fought back, screaming, stealing, and becoming as 'fierce' as he believed his informants to be (1983: 9). After some time I realized that the unspoken was extremely significant. Not being allowed to go to a certain place inevitably meant that it was a volatile area of unresolved conflict that had occurred before my arrival - a taboo topic for normal conversation. Had I been living alone, I would have never discovered the subtexts to seemingly paranoid social interactions and behaviours. Talking to outsiders eventually became possible, but only after several months of building trust. In the end I learned that respectful conduct was not only a better way to secure informants' trust but ultimately gave me more freedom. Maintaining good relations in one's field site is also an obligation for the sake of future researchers, something anthropologists have learned the hard way in native North American and Amazonian communities (Peers \& Brown 2003).

Being aware of a community's unspoken and concealed past was crucial in my case because generations of alliances and disputes had framed the rules that would govern how I could interact with community members. Simply by choosing to live with a

\footnotetext{
${ }^{3}$ While Bowen's account is fictional, it is representational of her and many other anthropologists' fieldwork experiences.
} 
particular household I had inadvertently made my alliance, limiting whom I could visit and where I could go. I found this out early when I went to interview a prominent musician and was told she could not speak because of 'an attack of the nerves' that came and went periodically. Over the next few weeks, her 'nerves' always seemed to attack when I came to visit. I later discovered that the woman had been part of a music group with members of the family I lived with, but had split up with them years before on bad terms.

Constant surveillance and limitation of movement may not be as constraining as they initially appear. Re-evaluating the strong sense of 'independence' that so many anthropologists necessarily possess is an important preliminary step in this type of fieldwork situation. For researchers from places where children are socialized to not rely upon or be obliged to others, this becomes a liability in the field when forming relationships with others. This re-evaluation is also part of learning local expectations and the obligations that a host family feels for the safety of a new family member. 'Having someone along' to keep an eye on me was more flexible that it first seemed - the kid that was sent out with me inevitably wandered off to a relative's house - and in a sense gave me more freedom because I gained access to places I would not have felt safe in alone. I also avoided unwanted attention by not conducting my transactions as a woman alone in a very machista society. Instead of fighting against rules that initially felt restrictive, I learned to work within the constraints of a community paranoid about violence.

Initially, I was a very suspicious character, not only as an outsider but as a U.S. national asking questions about people's family members abroad. On a couple occasions I faced joking accusations of being an undercover U.S. Drug Enforcement Authority agent. I denied these light-hearted accusations but also realized that I would have to invest a significant amount of time in gaining the trust of informants and making my research transparent (three years of working on this project with informants' families in the U.S. and in the Dominican Republic has significantly increased my credibility with informants). These initial accusations reminded me that I was an American in a country with a long history of U.S. military occupations. ${ }^{4}$ High inflation of the Dominican peso (a reflection of U.S. dollar fluctuations) fueled anti-American feelings. ${ }^{5}$ Mistrust towards my intentions was further complicated by conducting research during wartime, another aspect of fieldwork in insecure contexts. Anti-American feelings were revived by the widely unpopular war in Iraq unfolding before everyone's eyes on television each evening. The fact that many families had relatives in the U.S. military or incarcerated in New York (where it was believed they would be vulnerable to terrorist attacks) gave global conflict a very negative personal dimension, and informants often demanded my political views and a justification for the war.

Globalized technology ensures that the anthropologist is never free from her own country's conflicts or their potential for affecting interactions with informants. Rather than Malinowski's mossy stone, the ethnographer is a walking political target, evidenced by the decreasing choice in research areas, specifically in the Middle East,

\footnotetext{
4 The U.S. military occupied the Dominican Republic from 1916 to 1924 during the economic instability following the death of President Ulises Heureaux. The military invaded again in 1965 to quell what was feared as 'communist' uprisings in a time of political unrest.

${ }^{5}$ The peso tripled in 2003 and 2004 from RD\$16/U.S.\$1 to RD\$50/U.S.\$1.
} 
available to my cohort of English and American graduate students. I am reminded of an American colleague who recently left Morocco because of death threats, a Palestinian ethnographer wary about continuing a project in Israel, and a Welsh colleague fearful in Yemen during terrorist attacks. These are the realities and constraints of citizenship playing out today as they have in the past for anthropologists, but I would suggest that the situation is only becoming more complex as media increasingly brings controversial conflict to the remote corners of the world. As Renato Rosaldo points out, anthropologists do not easily disengage themselves from the power structures that they represent (1986: 78).

Only time can help the anthropologist be seen less as a probing stranger and more as a person based on her own merits. In contemporary times as much as in the past, classical anthropological methods of participant observation and long-term stays become crucial to gaining the quality of interaction and trust necessary for intimate and holistic understandings of society. Not only must we be researchers but also ambassadors with long-term relationships in mind, considering outcomes for informants and compensating them for knowledge extracted (Peers \& Brown 2003, Smith 1999). Globalized communication and cheaper, faster transportation facilitate long-term interactions but also heighten the impact and accessibility of research, providing good incentives for anthropologists to recheck ethical responsibilities.

\section{Fieldwork training recommendations}

In closing I would like to offer recommendations (learned through trial by fire as opposed to academic training) not just to researchers working in violent or nonviolent locales but also to departments training students for their first fieldwork experiences. There are a number of obstacles that keep fieldwork methodology training a low priority in academic anthropology departments. It may seem redundant for already overworked professors to lecture on apparently obvious methods such as emailing notes back home, maintaining confidentiality of informants, and securing equipment. Being street smart is not something one can necessarily teach in a classroom. Moreover, the increasingly international admissions of anthropology departments in the UK may give the impression that students have extensive experience travelling and therefore do not need to be taught how to conduct or protect themselves in foreign countries. Added to these assumptions is the widespread attitude among anthropologists that unfortunate experiences are in some way a rite of passage for the ethnographer, part of the accepted vulnerability of being a newcomer and getting mugged or catching malaria. These attitudes are reinforced by the hardened bravado of development workers in field sites who are encouraged by their superiors to ignore their dysentery and plow on with a task.

Despite these prevailing attitudes, we should not take for granted that students will know how to deal with the logistical aspects of data collection, personal safety, or conflict. Not all researchers come from urban areas and are street smart, and the field is increasingly filled with women travelling alone. Current systems of placing primary responsibility on individual supervisors for giving 'advice' to students results in a hodgepodge of unequally distributed information. Discussions in field research seminars are well intended but not sufficient. What is needed, where it does not already exist, is a mandatory fieldwork protocol of standardized procedures for data collection and schedules for sending notes home electronically. Medical and personal safety seminars would be another extremely helpful tool for any researcher. Making 
methodology a high priority shows an institution's commitment to safe and ethical research.

While not wanting to be butterfly collectors, there are times when rigid structure in anthropological fieldwork is appropriate, such as in the practical matters of data management, personal safety, and ethical guidelines while conducting fieldwork. In the words of Frank Pieke researching in Beijing during the Tiananmen Square riots, adversity and conflict may change original project plans, but can still produce interesting findings (2000: 143). With the right precautions and ethical priorities made explicit in fieldwork training on the institutional level, contemporary fieldworkerseven under adverse conditions - can find a middle ground that balances personal safety and risk without sacrificing the trust of informants and quality of interactions crucial to furthering the anthropological legacy of nuanced and multi-layered humanistic interpretation.

\section{References}

Abu-Lughod, L. 1986. Veiled sentiments: honor and poetry in a Bedouin society. Berkeley: University of California Press.

Bourgois, P. 1995. In search of respect: selling crack in El Barrio. Cambridge: Cambridge University Press.

Bowen, E.S. 1964. Return to laughter: an anthropological novel. New York: Anchor Books.

Chagnon, N.1983. Yanomamo: the fierce people. New York: Holt, Rhinehart and Winston.

Howell, N. 1990. Surviving fieldwork. Washington, DC: American Anthropological Association.

MacClancy, J. 1988. Going nowhere: from Melanesia to the Mediterranean. Journal of the Anthropological Society of Oxford. 19 (3): 233-40.

Nordstrom, C. 1997. A different kind of war story. Philadelphia: University of Pennsylvania Press.

Peers, L. \& Brown, A. 2003. Museums and source communities: a Routledge reader London, New York: Routledge.

Pieke, F. 2000. Serendipity in anthropology and culture. Anthropologists in a wider world: essays on field research (eds) P. Dresch, W. James, \& D. Parkin. New York, Oxford: Berghahn.

Rosaldo, R. 1986. From the door of his tent: the fieldworker and the inquisitor. Writing culture: the poetics and politics of ethnography (eds) J. Clifford \& G.E. Marcus. Berkeley: University of California Press.

Scheper Hughes, N. 1979. Saints, scholars and schizophrenics. Berkeley: University of California Press.

Smith, L.T. 1999. Decolonizing methodologies: research and indigenous peoples. London: Zed Books. 


\section{About the author}

Hannah Gill is currently a Rockefeller Postdoctoral Scholar at the University of North Carolina at Chapel Hill, teaching classes on immigration and conducting research on Mexican immigrants in the local community. She wrote her dissertation in social anthropology at the University of Oxford on transnational migration, religion and music in the Dominican Republic. 